\title{
The 1619 Project and Living in Truth
}

\section{SEAN WILENTZ}

The current woes in American historical studies should have come as no surprise. The writing of history is always sensitive to changing cultural and political circumstances, in the United States no less than elsewhere. Every thirty years or so it seems that a struggle arises over whether the history being taught in America's schools is sufficiently patriotic. The struggles derive in part from political machinations but also from developments inside the historical profession, which, in turn, are shaped by shifting political and cultural trends.

The origins of today's battles date back to the 1960's and 1970's, when an outpouring of scholarship, inspired in part by the rise of civil rights movement, established indisputably the centrality of slavery and racism in U.S. history. Coupled with a broader shift toward writing history from the bottom up (as the phrase went), the revisionist writing on slavery and race was bound to cause a stir sooner or later, especially after the nation's politics turned sharply to the right during Ronald Reagan's presidency. Sure enough, in 1994, under the liberal administration of Bill Clinton, Reagan-style conservatives and talk radio polemicists, along some academic critics, launched bitter attacks on a federally-sponsored effort to establish National History Standards for teaching U.S. history in the schools. The proposed standards fully reflected the revisionist historical scholarship of the previous thirty years, which the conservatives blasted as imbued with anti-American multiculturalism. In January 1995, the U.S. Senate rejected the standards by a vote of 99 to 1 . An independent panel of historians, including Arthur M. Schlesinger, Jr., attempted to counter the polarization and recommended that the standards be revised but not scrapped; and the composers of the standards duly revised them. The fight ended only when the government finally gave up on the entire standards program. ${ }^{1}$

The History Standards controversy left behind poisonous bad feelings, and the disjunction between historical study and mainstream presentations of American history continued to grow. The subject of history, though, seemed to recede from the culture wars, only to reemerge, after a fashion, during the presidency of Barack Obama. Prior to the 2010 midterm elections, hardline conservatives - dubbing themselves the Tea Party to co-opt a rebellious event in the run-up to the American Revolution - politicized

There is an abundant literature on the National History Standards controversy. For two differing views, see Diane Ravitch, The Controversy Over the National History Standards, Bulletin of the American Academy of Arts and Sciences, 51, 3 (January-February, 1998), pp. 14-26; and Gary Nash, Reflections on the National History Standards, National Forum (Summer, 1997). I offered my own assessment in Sean Wilentz, Don't Know Much About History, New York Times Book Review, November 30,1997. The one vote in the Senate that did not support censuring the standards came from a Louisiana senator who thought the Senate's action an insufficient rebuke. 


\section{/ HISTORIOGRAPHY /}

historical motifs in order to mobilize and inflame popular opposition to Obama, as if liberalism was the imposition of tyranny. ${ }^{2}$ Some on the right, following the lead of the real-estate mogul and TV reality-show star Donald J. Trump, charged that Obama was secretly an African-born Muslim whose election to the White House was in violation of the Constitution. Then, after Trump's election to the presidency in 2016, struggles over history exploded anew. Trump's racialized rhetoric had a great deal to do with the tumult, but so did continuing reappraisals of American history that by now extended well beyond the nation's universities and colleges.

Indicative of these reappraisals was a rising public concern, again from the ground up, about monuments that had been erected in the southern states long after the Civil War to honor the slaveholders' rebellion and to commemorate, even idolize the leaders of the Confederacy. ${ }^{3}$ The monuments, put up after Reconstruction was violently suppressed by white terrorist organizations like the Ku Klux Klan, were, to many, hateful symbols of the disenfranchisement of black Americans and the new system of Jim Crow segregation. Their adversaries bridled, some regarding the monuments as intrinsic to southern heritage, others charging that removing the monuments amounted to air-brushing the past.

The issues at stake had less to do with history per se than with historical memory, and with whether the glorification of events and people connected with the perpetuation of slavery and white supremacy ought to be tolerated any longer. Nevertheless, clashing historical interpretations came into play, over the legacy as well as the origins of the Civil War; and these interpretations shaped the fights and the subsequent political polarization. It was, we need to remember, a local controversy over the mandated removal of a statue of Confederate general Robert E. Lee in Charlottesville, Virginia, that led to the shocking and finally deadly fascist rally that in turn led to Trump's notorious remarks calling the racist and anti-Semitic mob "fine people“ and supporting the „beautiful statues and monuments" that the white supremacist, neo-Nazi Right claimed emboldened them. ${ }^{4}$

Even as the traumatic events unfolded in Charlottesville, though, fresh battles over American history were building, involving issues above and beyond how Americans ought to remember their Civil War. Those battles raged amid the turmoil of 2020 that followed George Floyd's despicable murder at the end of May. As far as I was concerned, though, they broke out several months earlier, during the summer of 2019.

2 See above all Theda S rocpol and Vanessa Williamson, The Tea Party and the Remaking of Republican Conservatism, New York 2012.

3 For a strong account of the statues controversy, from the standpoint of a southern mayor who ended up on the side of removal, see Mitch Landrieu, In the Shadow of Statues: A White Southerner Confronts History, New York 2018.

4 There has been considerable controversy over these remarks of Trump's, to the point of questioning whether he meant what the words appeared to mean. For considerations see Trump Defends 'Beautiful' Civil War Statues, BBC News, August 17, 2017; Glenn Kessler, The 'Very Fine People' at Charlottesville: Who Were They?, Washington Post, May 8, 2020. 


\section{The 1619 Project Arrives}

On a hot, drowsy August Saturday, a copy of the New York Times Magazine devoted entirely to something called The 1619 Project landed on my doorstep, and immediately grabbed my attention. It took me little time to comprehend the project's purpose, or what appeared to be its purpose. Historians, if not the public, identify 1619 as the year the first African bondsmen arrived in the British colonies that would become the United States. Clearly, or so it seemed, the Times, at a fraught moment in the nation's race relations, had commendably decided to popularize half a century's worth of historical research on American slavery, race, and racism, as a rejoinder to the alarming spread of pro-Trump white nationalism. The Times's list of the project's contributors included some names I recognized and respected, although it did seem odd that the list lacked any historian with expertise on the history of the United States before 1865, which would include, of course, the entire history of American slavery. Still, I thought, better an uneven rendering than none at all, so long as the rendering was intellectually reliable.

But I began feeling uneasy a few minutes into reading the lead essay, by the project's chief contributor, the journalist Nikole Hannah-Jones, and then I read a key paragraph so fallacious and dogmatic that it hit me between the eyes. With a tone of absolute assurance, flagging the matter as crucial, the essay informed readers of what it called a "fact" - a fact "conveniently left out of our founding mythology" - specifically that "one of the primary reasons the colonists decided to declare their independence" from Britain „was because they wanted to protect the institution of slavery. ${ }^{\text {" }}$

I instantly wondered how anyone even lightly informed about the history of either slavery or the American Revolution, could write that sentence. Unfortunately, the ensuing explanation only made matters worse. The British, the essay claimed, had grown „deeply conflicted“ over slavery, and the British government was facing rising calls to end the Atlantic slave trade - a reform that would have „upended“ the entire colonial economy, not just in the South. For that reason - the essay mentioned no other - the American colonists, North and South, believed that the British posed a threat to slavery, an institution they desperately wanted to protect. Rather than run the risk of losing slavery, the colonists declared their independence. The Revolution was supposedly, at its core, a reactionary, proslavery struggle to fend off abolition of slavery by the British. ${ }^{6}$

The paragraph covered subjects of unsurpassed importance and it was historical gibberish. As I would later confirm with the foremost scholars of the subject who know far more about the Revolution than I, there is no evidence of a single colonist expressing

Nikole Hannah-Jones, America Wasn't a Democracy Until Black Americans Made It One, New York Times Magazine, August 14, 2019. The version posted online as of June 8, 2021 contains the two words added in the „clarification“ discussed below, which restated the text to say that only some Americans fought for independence in order to protect slavery.

6 IBIDEM. 
support for independence in order to protect slavery. The 1619 Project's claims were based not on historical sources but on imputation and inventive mindreading - and that was just for starters. The British were not „deeply conflicted“ over slavery in 1776. Neither were there loud outcries in London against the slave trade until years after the American Revolution. Nor did the colonists believe that ending the slave trade would severely damage their entire economy. It was the Americans, and not the British, who loudly called for abolishing the trade, albeit not always for humanitarian reasons, in petitions that Crown officials rejected out of hand. Indeed, at the time of the Revolution, there was considerably more in the way of anti-slavery politics in the colonies than in Britain proper. ${ }^{7}$ These are elementary facts.

Slavery certainly existed in 1776, in all thirteen colonies, and it had ardent and powerful defenders, especially in the lower South, and many of the leading lights of the American cause, above all Thomas Jefferson and George Washington, owned, bought, and sold human beings. Mindreading and inventions aside, though, the evidence, or absence of evidence, make it clear: fear of a rising abolitionism in Britain was not a ,primary" cause of the Revolution - or, for that matter, any cause at all. The very existence of such dedicated and influential rebels as John Adams and Thomas Paine, who reviled slavery, as well as Benjamin Franklin, who went on to head the Pennsylvania Abolition Society, confuted the essay's claim. So, even more, did the fact that many if not most of the leading Loyalists in the lower South were slaveholders. If protecting slavery really was a primary cause of the Revolution, why did these enslavers support the Crown? Did nobody tell them about the fearsome, incipient British abolitionist threat? Slavery can account for a good deal in early American history, far more than previous generations of historians thought, but it cannot account for everything.

It required no advanced knowledge of American history to understand the perversity of The 1619 Project's lead essay's treatment of the Revolution. If it were a high school history paper, that discussion alone would have been grounds for failure. It's rare, after all, to read a student get every single stated fact perfectly wrong, in support of a proposition for which there is no other evidence cited, on two of the most important topics in all of U.S. history, indeed, all of modern history, the causes of the American Revolution and the origins of antislavery. But this wasn't a high school paper, it was the New York Times Magazine, and the author was, according to her contributor's biography, a highly

On this last point, see Roger Bruns (ed.), Am I Not a Man and a Brother: The Antislavery Crusade of Revolutionary America, 1688-1788, New York 1977, as well as Sean Wilentz, No Property in Man: Slavery and Antislavery at the Nation's Founding, Cambridge, MA, 2018, pp. 25-57. Hannah-Jones's essay does manage to quote in passing the white abolitionist and supporter of the Revolution Samuel Bryan without saying anything about the antislavery aspects of the American Revolution. One would never imagine, for example, on the basis of her presentation, that between 1780 and 1784, five of the seven new states north of Delaware adopted the first important emancipation measures of their kind in the Atlantic world. 
acclaimed journalist. The essay may have been historically fallacious, but it was also inflammatory and attention-getting.

There was nothing else in the keynote essay quite so egregious as its discussion of the American Revolution, but there was plenty that was either patently tendentious (e.g., that Abraham Lincoln was a racist who opposed Black equality) or simply false (e.g., that American Blacks fought for equality after the Civil Was for the most part entirely on their own). The ensuing individual essays were for the most part better, although the quality of historical research and reasoning varied considerably from contribution to contribution.

By the time I had finished the entire thing, the shape and purport of the project as shaped by its editors were clear. (If every essay did not espouse the same framework, all could be assimilated to it.) Instead of trying to instruct the public about the significance of the year 1619, and hence of the foundational importance of slavery and racism to American history, the project promoted a narrow, highly ideological view of the American past, according to which white supremacy has been the nation's core principle and chief mission ever since its founding. Everything, supposedly, that has happened since to make the United States a distinctive country is rooted in slavery and the subsequent debasement of Blacks. America has not really struggled over the meaning of its egalitarian founding principles: those principles were false from the start, hollow sentiments meant to cloak the nation's reliance on and commitment to the subjugation of Black people - principles claimed and vindicated, to the extent they have been, by Black Americans struggling pretty much on their own. And now, thanks to The 1619 Project, that suppressed history would at last, for the first time, come to light, with the esteemed imprimatur of the New York Times.

Although touted as startling revelation, the enterprise had an old-fashioned ring to it, reminiscent of long-discredited polemics from decades ago, including the writings of the Ebony magazine editor and Black studies historian, the late Lerone Bennett Jr., who compared Lincoln to Adolf Hitler. (Indeed, Hannah-Jones later credited Bennett as one of her chief inspirations.) Like those earlier broadsides, The 1619 Project appeared to be interested chiefly in molding history in order to push a particular political cause, which in this case has turned out to be demanding that the government pay financial reparations to Blacks as compensation for slavery and racism. ${ }^{8}$

Bennett's key works are Lerone Bennett JR., Before the Mayflower: A History of the Negro in America, 1619-1962, Chicago 1962, a collection of articles originally written for Ebony surveying its subject, praised at the time by the historian Benjamin Quarles as lively, deeply-informed, and moving if not especially original; and the more controversial Lerone Bennet T Jr., Forced Into Glory: Abraham Lincoln's White Dream, Chicago 2000. Quarles's review appears in American Historical Review 68, No. 4 (July), 1963, pp. 1078-79. See also Eric Foner, Was Abraham Lincoln a Racist?, Los Angeles Times Book Review, April 9, 2000; and James M. McPherson, Lincoln the Devil, New York Times Book Review, August 27, 2000. On Hannah-Jones and Bennett, see Sarah Ellison, How 1619 Took 


\section{Historians Respond}

Although surprised that the New York Times would lend its name and credibility to such a crude and falsified account of American history - a history with more than enough brutality, racism, and systematic oppression to require no falsification - I put the magazine aside. Responsible historians, I assumed, would come along soon enough to praise the project's stated goals while debunking its skewed and sometimes warped history, just as historians had done decades ago in response to the writings of Lerone Bennett and others - and seen their refutations prominently published in, among other places, the New York Times. As for the outright factual errors, I imagined that some bright young historian who could use the attention would write a letter to the editor of the Times Magazine, asking for corrections - corrections that, I thought, the Times, adhering to its longstanding professional standards, of course would make.

When no letter appeared and no other historians spoke up, I decided to address the matter myself in a public lecture I delivered in November, which would later appear online in the New York Review of Books. ${ }^{9}$ Only after the lecture did I learn that four highly distinguished historians - three of them old friends and colleagues, the fourth a scholar I greatly respected - had already been giving interviews to an online forum called the World Socialist Web Site, a Trotskyist venue, taking The 1619 Project seriously to task for its false statements about the Revolution and much more. ${ }^{10}$ The four included Victoria Bynum of Texas State University, a distinguished scholar of the Civil War South and white resistance to the Confederacy; James Oakes of the Graduate Center at the City University of New York, the premier scholar of, among other subjects, the politics of Emancipation; as well as Gordon S. Wood of Brown and James M. McPherson of Princeton, the greatest living authorities on, respectively, the American Revolution and the American Civil War.

It struck me as a little odd that these well-known historians - none of them socialists as far as I knew, let alone Trotskyists - would appear in such a relatively obscure place. Surely, I thought, one of the leading academic journals would have given them

Over 2020, Washington Post, October 13, 2020. On the connection to the demand for reparations, see Hannah-Jones's follow-up article to her 1619 contribution, N. Hannah-Jones, „What Is Owed,“ New York Times Magazine, June 30, 2020.

9 See Sean Wilentz, American Slavery and 'the Relentless Unforeseen, New York Review of Books, November 19, 2019. The essay was drawn from the fourth annual Philip Roth Lecture delivered at the Newark Public Library, Newark, New Jersey, on November 4, 2019.

10 The interviews have now been collected in David Nort - Thomas Mackaman (edd.), The New York Times's 1619 Project and the Racialist Falsification of History, Oak Park, MI, 2021. The WSWS subsequently interviewed several other distinguished scholars who were equally critical of the project: Clayborn Carson of the Martin Luther King Jr. Papers/Stanford University; Richard Carwardine of the University of Oxford; Dolores Janiewski of Victoria University of Wellington, New Zealand; and Adolph Reed, Jr. of the University of Pennsylvania. 
a platform. As it happened, only the intellectually honorable Trotskyists, whatever one thought about their politics, had the nerve to undertake a systematic critique of The 1619 Project. Still, I was encouraged to discover that I wasn't alone in my criticisms. Likewise, I thought that, by appearing on a leftist website, my colleagues at least could not be conflated with the right-wing attack squad, headed by former House Speaker Newt Gingrich, which had been lambasting the project from the moment it appeared. ${ }^{11}$ Unlike during the History Standards controversy in 1994, I thought, this dispute needn't become sharply polarized between the Left and the Right. And if it did become divisive, perhaps liberal minded scholars (including some, like myself, with political credentials on the Left) could be seen as honestly critical of a supposedly „progressive“ historical undertaking. Perhaps we could speak out without running the risk of being derided as de facto or "objective“ accomplices of Gingrich and company. Perhaps we could play a role not unlike that of the liberal historians a quarter century earlier who opposed rejecting the History Standards proposals but suggested revisions, with some success. Looking back on it now, I couldn't have been more naive.

Encouraged by my colleagues' interventions yet disappointed when the Times ran no correction of the errors, I contacted the others with the idea of writing a joint letter to the editor of the Times Magazine. My colleagues had had their independent say on the WSWS, as I had in my published lecture. Now was the time to engage the Times Magazine directly, to see what we could do to express our solidarity with its stated aims while also pointing out the serious lapses in execution. The objective would not be to contest The 1619 Project's specific interpretations or general arguments, about which the five of us had different ideas. Substantive disagreements about history, we agreed, require extended articles, not letters to the editor, which serve a different purpose. We would stick to matters of fact, starting with the American Revolution, and ask for simple corrections of the errors the Times had committed to print.

It was crucial, we thought, to get the facts straight, primarily for the sake of the public record but also to fend off right-wing hostility to the very idea of a major series on slavery and racism, and their vital connections to current grave inequalities. Better to clear the air, make the kinds of responsible corrections every newspaper makes, and then go on to debate what the facts mean, insistent that there is more than one way to interpret any historical issue. Our own disagreements with some of the project's substance and interpretations were profound, but with regard to our letter, they were completely beside the point. We instead wanted to insure, as best we could, that public understanding and discussion would proceed from reliable history. We tried to write a letter that would make this clear. By undertaking the necessary corrections, responsibly, straightforwardly, and without rancor, the

11 Nicholas Wu, Newt Gingrich Says Slavery Needs to Be Put 'In Context,' Calls 1619 Project a 'Lie,', USA Today, August 19, 2019. 
Times, we were certain, would enhance The 1619 Project's credibility, not diminish it. After all, the Times was forthrightly devoted to objectivity and reason.

We went back and forth working over a draft letter, trying to keep our remarks concise, then sent the final letter to the Magazine's editor-in-chief, Jake Silverstein. We also duly sent copies the newspaper's publisher and some other top editors to reinforce the seriousness of our objections. The idea of communicating our concerns privately to the Times, in a cloaked manner - with the additional idea that corrections would suddenly appear out of nowhere, months after the 1619 articles appeared - never occurred to us. Writing letters to the editor is how these matters proceed in an open, reasonable society, although we had no guarantee that the letter would actually appear. Acknowledging and regretting errors is something newspapers do all of the time, with unfeigned sincerity, sustaining the bonds of trust among writers, editors, and readers. We never imagined that saving face would take precedence over getting the facts straight.

\section{The Controversy}

There were, to be sure, some early signs around the time we were drafting the letter that trouble was brewing. Hoping to expand the group beyond the five of us, we sent copies of an early draft letter confidentially to various colleagues - Black and white, men and women, scholars with special expertise in the fields that most concerned us - asking if they would be willing to sign as well, and to send any revisions they might have to suggest. (As all five of us are white, we were especially hopeful that one or more Black historians would sign on.) However, we received very few responses, and those that arrived gave one excuse or another for declining. It seemed clear that although many of our colleagues agreed with our criticism as they explained in private, they were wary of saying so publicly. That should have been a warning that we were treading into toxic territory, which became all the clearer when, just as we sent the letter to the Times, journalists began contacting me, asking questions about an earlier draft which they assumed was the same as the final draft. Plainly, one or more of the historians we'd contacted had decided to leak the contents of the draft to unfriendly members of the press, and quite possibly to the 1619 editors and staff. Perhaps they sent the draft directly to the 1619 editors, who then passed it on to writers outside the Times. Either way, we knew it spelled trouble.

Some people clearly were infuriated at our pointing out errors that needing fixing, interpreting any criticism at all as hostile act. Even if the errors, on subjects as vital as slavery and the American Revolution, seriously undermined the project's credibility as well as its interpretation, pointing them out publicly seemed to be an act of betrayal that amounted to intolerable heresy. Yet we remained confident when we received a friendly email from one of the Times editors acknowledging receipt of our letter, which seemed to affirm our good faith. We then received word that the Magazine would indeed be publishing the letter in late December. I imagined that the Times would run the usual 
brief editor's note, own up to the mistakes, and revise the copy that appeared on the newspaper's website.

The lengthy reply from the Magazine's editor, Silverstein, published alongside our letter and more than three times longer, was deeply disappointing. ${ }^{12}$ Silverstein refused to make any corrections because, he countered, there was nothing to correct! He then spent the remainder of his lengthy reply unintentionally refuting that claim.

Silverstein's evasions showed that, in fact, he knew very well that Hannah-Jones's essay demanded corrections, but that he had decided to opt for damage control rather than responsibility. Instead of providing evidence to back up Hannah-Jones's erroneous arguments that our letter identified, he substituted new arguments of his own, as if they were the same as Hannah-Jones's, and defended them. (On even cursory inspection, these substitute assertions, based in part on a debunked book by a pair of non-historians, proved just as erroneous as Hannah-Jones's originals.) He ignored our objections about the project's false statements on British antislavery, the slave trade, and American Revolution, as if pretending that errors don't exist is the same thing as proving they don't exist. He brought up details that Hannah-Jones never discussed, about the landmark Somerset decision in Britain in 1772 and the promised liberation of Virginia slaves by a British officer in 1775, as if on a frantic mission to find something, anything, which might prove that a chief purpose of the Revolution was proslavery. As I would explain in a later essay of my own, these portions of Silverstein's reply misreported basic facts, turning them into their opposite, and cropped historical documents, thereby altering their meaning. Even then, however, flimsy as the corrupt documentation was, it did nothing to affirm the project's account of slavery and the Revolution. ${ }^{13}$ Then Silverstein turned to prevarication. To our objection about The 1619 Project's absurd claim that Blacks had to fight for civil rights after the Civil War for the most part on their own, he said nothing, although he did remark that African-Americans have taken the lead in struggles to secure the rights of minority groups, a perfectly accurate and perfectly obvious observation that contradicted nothing in our letter. ${ }^{14}$

How much Silverstein, who is no historian, actually believed in the truth of this arcane nonsense, or wanted to believe in it, or invented it himself, is unclear. How much his response was defensive, as if admitting error would have been a disgrace, is likewise unclear. Readers of the Times may never know how much internal politics at the newspaper - an institution that, the world would later learn, was convulsed with ill feeling on matters of politics and race, and wracked by cliques - contributed to what happened. Perhaps, given the lavish public relations campaign that the Times mounted

12 The historians' letter and Silverstein's reply appear as J. Silverstein, We Respond to the Historians Who Critiqued The 1619 Project, New York Times Magazine, December 29, 2019.

13 Ibidem. My article appeared as Sean Wilentz, A Matter of Facts, The Atlantic, January 22, 2021, intended in part as a response to Silverstein's reply.

14 J. Silverstein, „We Respond.“ 
on the project's behalf - including a slickly produced television ad broadcast during the Oscars broadcast (a heavy media buy!) and then posted all over social media - the paper was intent on keeping the 1619 brand untainted. Perhaps a desire to prevent prize juries from souring on the project, above all the Pulitzer Prize juries - presumably a prime target audience for the extravagant marketing blitz - played a role as well $1{ }^{15}$. Whatever the reason or reasons, though, Silverstein's adamant insistence that Hannah-Jones's essay was perfectly correct and proper in every respect- an argument that his own flawed response badly damaged - soon enough collapsed.

In March, a few weeks after our letter and Silverstein's reply appeared, the U.S. historian Leslie M. Harris, at Northwestern University, who happens to be an African American woman, revealed that she had been contacted by the Times' fact checkers in connection with The 1619 Project and that she had explained to them, vigorously, that the material on the Revolution was flat out wrong, but that her objections were ignored. In our letter to the editor, we historians had objected to the closed process whereby the project's materials were vetted and we had asked for more transparency. In his published reply, without going into details, Silverstein assured the Times's readers that „during the fact-checking process, our researchers carefully reviewed all the articles in the issue with subject-area experts." He did not disclose that, as part of that careful review, the 1619 editors simply ignored at least one subject-area expert's fervent objections on a major subject. When asked to explain, Silverstein revealed nothing. ${ }^{16}$

Shortly thereafter, goaded by the behind-the-scenes complaints of another leading African American scholar, Danielle Allen of Harvard, who warned she would take them public, the Times Magazine ran what it called a "clarification, “ inserting two words into its online version of the project's lead essay, now stating that only „some“ Americans fought the Revolution primarily to protect slavery. The revision actually confused more than it clarified - „some“ could mean that as few as two people out of millions feared slavery's demise, for which no evidence actually exists anyway - while it left intact the original false statements about British antislavery and the Atlantic slave trade. Then,

15 Several episodes roiled the Times newsroom in 2020 and 2021, including internal dissension over a column critical of The 1619 Project written by one of the paper's regular columnists, Bret Stephens. The most consequential incident involved the forced resignation of a veteran science reporter, Donald $\mathrm{McNeil}$ over allegations that he had made racially insensitive remarks to a group of high-school students on a Times-sponsored trip to Peru in 2019. For coverage, see, for example, Brian Stelter - Oliver Darcey, 1619 Project Faces Renerwed Criticism - This Time From Within the New York Times, CNN Business, October 12, 2020; and Joe Pompeo, 'It's Chaos': Behind the Scenes of Donald McNeil's New York Times Exit, Vanity Fair, February 10, 2021. On the marketing and public relations efforts on behalf of the 1619 Project, see the Times's coverage of its own Oscars ad at https://www.nytco.com. That the media blitz was accompanied by the slogan „The Truth Can Change How We See the World," made it all the hollower.

16 Leslie M. Harris, I Helped Fact-Check the 1619 Project. The Times Ignored Me, Politico, March 6, 2020; J. Silverstein, „We Respond.“ 
over the following summer, Hannah-Jones herself confessed that she was „tortured“ by the fact that she hadn't sufficiently consulted historians of the Revolutionary or Civil War eras ${ }^{17}$ Around the same time, critics discovered that, as the objections to $1619 \mathrm{had}$ mounted, the Times silently revised substantive claims in that portion of its website devoted to the project without public acknowledgement that it had done so, in violation of its normal professional practice. ${ }^{18}$ Meanwhile, in public and in private, Hannah-Jones resorted to personal attacks on her critics, including a broad-brush dismissal of factual objections as the work of biased „white historians. " ${ }^{19}$

\section{9 and the Politics of 2020 and Beyond}

Once the Covid pandemic truly hit, and the events of the late spring and summer of 2020 unfolded, the debate over The 1619 Project became entangled in larger controversies: over the unprecedented, thundering, passionate Black Lives Matter demonstrations to end violent and discriminatory policing, especially following the murder of George Floyd; over the violence and looting that were separate from the BLM demonstrations but took advantage of their cover, and which led to billions of dollars of property destruction, much of it in black communities, and which Hannah-Jones celebrated as „the 1619 riots“; over so-called „woke“ politics and reprisals against those holding heretical non- or anti-"woke" opinions; and, above all, over the fervor on the right, whipped up by President Trump and his accomplices, that culminated in the deadly attack on the Capitol in the insurrection of January 6,2021, intended to prevent the certification of the presidential election. ${ }^{20}$

Some of our worst fears of what might result from the Times's refusal to correct The 1619 Project's errors came to pass. As was later reported in the Washington Post, early in January 2020, I had met over lunch with Jake Silverstein in Manhattan at Silverstein's invitation. Despite our clash in print, I hoped to clarify my concerns about the project and find some common ground. I warned him directly that, unless the Times corrected the errors in 1619 and then tempered its inflammatory message, the Republican right would seize upon it and turn it into a divisive political issue in the looming national election campaign. Newt Gingrich, I informed him, had already been making noises about Trump and the Republicans doing precisely that. Silverstein, sticking straight-faced to his claim that no corrections were called for, scoffed at the very idea. ${ }^{21}$

17 S. Ellison, How 1619 Took Over 2020.

18 Imidem; Philip W. Magness, Down the 1619 Project's Memory Hole, Quilette, September 10, 2020.

19 Jake Silverstein tried to defend one episode of Hannah-Jones' attacks on „white historians“ in his reply to Our letter: J. Silverstein, „We Respond.“ See also S. Ellison, How 1619 Took Over 2020.

20 On Hannah-Jones and the „1619 Riots,“ see IBIDEM.

21 IBIDEM. 
But Gingrich wasn't kidding. (Anyone who knows the recent history of American politics knows that Gingrich threatens but doesn't kid.) As the campaign began heating up in September, the demagogue Trump pounced on the project's mistakes and turned 1619 into an emblem of violent leftist excess, even going to the trouble of establishing a presidential 1776 Commission to promote a dogmatic right-wing view of American history. How much Trump's condemnations of The 1619 Project and his conflation of it with socialism, calls to defund the police, violence, and looting - looting hailed by some on the Left as righteous rebellion - contributed to the Democrats' overall lackluster performance in 2020 is unknowable. But Rep. James Clyburn of South Carolina, a veteran of the 1960's civil rights movement and today the highest-ranking Black member in the House of Representatives, made clear that the violence and militant posturing severely hurt Democratic candidates; slogans like „defund the police, “ he remarked, had the potential to do to today's movement for racial justice „what Burn, Baby, Burn did to us back in the 1960s.“ Reputable polls supported Clyburn's contention about the public's hostility to radical sloganeering. ${ }^{22}$

The polarization of Left and Right was fierce, leaving the liberal critics of The 1619 Project stranded. The internal pressure to take sides became enormous, to the point where the editor of the nation's premier academic history journal, the American Historical Review, Alex Lichtenstein, decided to attack us, in his official capacity, as a "motley crew“ of egoistic grousers - alternatively, „Wilentz and the gang of four" - standing in the way of racial justice let alone intellectual progress. ${ }^{23}$ The style of such attacks on liberal dissenters to toe the ideological line would be depressingly familiar to anyone versed in the politics in Central or Eastern Europe since 1945, although the outcomes, obviously, were infinitely less grave.

A full account of these depressing events will have to await a more leisurely occasion, should one arise. Yet even as circumstances have grown more complicated, the character of the intellectual and academic troubles connected with The 1619 Project has become clearer. A few tendencies stand out. First, the prolonged era of regressive conservative politics that culminated in the authoritarian and racially-charged presidency of Donald Trump has badly flattened historical perspectives in the United States, inside as well as outside the academy. Historians as well as their readers and students are increasingly open to simplified, pessimistic, and even cynical caricatures of our past, especially concerning the history of race relations. Under Trump, the complicated history of struggle over slavery and racial oppression - a history where progress has always required bi-racial cooperation and

22 Holly Otterbein, A Conversation That Needs to Happen: Democrats Agonize Over 'Defund the Police' Fallout, Politico, March 23, 2021. Relevant polls includes Trip Brennan, What We Know - and Don't Know - About "Defund the Police" and the 2020 Election, Blue Tent, December 16, 2020; Steve Crabtree, Most Americans Say Policing Needs 'Major Changes,' Gallup Poll, July 22, 2020.

23 Alex Lichtenstein, From the Editor's Desk: 1619 and All That, American Historical Review 125, No. 1 (February) 2020, pp. xv-xxi. A response by myself and my four colleagues, along with Lichtenstein's retort appear as „Communications,“ American Historical Review 125, No. 2 (April) 2020, pp. 768-774. 
concerted government action against common foes - has faded before dogmatic versions of unceasing, virtually seamless white supremacy. Trump himself - and Fox News - bear heavy responsibility for the use of historical distortion for polarizing and even subversive ends. But so do ideologues with seemingly opposing political agendas of their own who feed off the pessimism that Trump reinforces, and who, having seized the mantle of righteous anti-racism, have attempted to turn reductive history into seductive history.

The response of the American historical profession to these events has often been dismaying. There are a few historians, even prominent ones, who not only endorse the kind of racial reductionism and essentialism promoted by The 1619 Project, but pursue it to strange lengths. These include a group of scholars (attracting some pundits, filmmakers, and activists) who argue that the Thirteenth Amendment to the Constitution in 1865 did not actually abolish slavery, as it purported to do, but actually installed slavery in the new and insidious form of mass incarceration - a view that one dissenting historian has criticized as „the scandal of Thirteentherism. ${ }^{24}$ Other historians are willing to overlook The 1619 Project's errors in the name of the greater good it supposedly brings to historical study and teaching, as if those errors were minor and as if the objections no more than pedantic nit-picking delivered in bad faith. Again, the fellow traveling behind falsehood would be familiar to central and eastern Europeans.

But it is also an open secret that many historians are simply intimidated about saying anything too loudly, too publicly, lest criticizing in any way The 1619 Projects or its offshoots invites being labelled and „mobbed“ as a racist on Twitter, thereby endangering their careers. Race relations, at least as perceived by the intelligentsia and the press, have become so embittered, and the promoters of supposedly anti-racist racialism have been so successful, that skeptics risk, or believe they risk, excommunication or being "cancelled" if they break with the new orthodoxy. The intimidation is especially powerful, for understandable reasons, among younger professors and graduate students braving a miserable job market. But in my own experience, even historians with secure positions and enviable reputations take refuge by stating, for example, that the jury is still out on whether American colonials' fear of British antislavery led to the American Revolution, while they admit there are scant records to substantiate the claim or no records at all. Others, including prominent historians, acknowledge privately that the project is riddled with errors and omissions but refuse to say so publicly.

The polarizing atmosphere naturally forces critics to clarify constantly where they stand in the culture wars. For my own part, that has meant writing articles strongly criticizing right-wing counters to The 1619 Project such as Trump's intellectually corrupt 1776 Commission. ${ }^{25}$ (It was nothing new for me to deride publicly Trump and

24 Daryl Michael Scotт, The Scandal of Thirteentherism, Liberties, No. 2, 2021, pp. $273-93$.

25 See, for example, Sean Wilentz, What Trump Doesn't Understand About U.S. History, Washington Post, September 23, 2020; IDEm, What Tom Cotton Gets So Wrong About Slavery and the Constitution, 
his flagrant abuse of history, but in the midst of the controversy over The 1619 Project, those criticisms now also signify that having qualms over the project did not imply endorsement of Trump's declamatory pseudo-history. $)^{26}$ When, in the spring of 2021, trustees at the University of North Carolina interceded to deny Hannah-Jones a tenured professorship at the university's journalism school, I felt it especially important to join with a more conservative colleague in criticizing the trustees' undue interference with faculty authority and indifference to academic freedom, as much as Hannah-Jones's appointment was open to serious question. ${ }^{27}$ (As it happened, the UNC trustees responsibly reversed their decision, only to learn that Hannah-Jones, while demanding that they do so, had in secret struck a better deal with a highly distinguished, historically-Black institution, Howard University, funded with $\$ 20$ million of support provided by, among other elite white institutions, the Ford Foundation.)

According to the sectarian logic of polarization, there must only be two sides. With so many tone-setting organizations promoting and attempting to enforce one version or another of ever-more sectarian language and racialist essentialism, in the worlds of major foundations and corporations as well within journalism and the academy, it's sometimes proven difficult to get heard above the din of finger-pointing accusations, party-line talking points, and ideological litmus tests.

The threat to a free and honest intellectual discourse, not to mention politics, is clear enough. When historians (or any other scholars) confuse the pursuit of truth with the pursuit of justice, we surrender our own credibility. Or as one of my colleagues, Gordon Wood, put it, „we all want justice, but not at the expense of truth. “28 Put still another way, subordinating truth to the demands of justice cannot be just, and may be a big step toward creating injustice, even tyranny. You in the Czech Republic have had to learn that lesson the hard way, repeatedly, over many difficult decades. „Living in truth,“ as Václav Havel described it, must be the basis for more than politics, including the study of history. It appears to be a lesson that many American historians, in far less onerous but still fragile and worrisome situations, must now learn for themselves.

New York Review of Books, August 9, 2020.

26 See, for a few examples from the 2016 campaign and then early in Trump's presidency, Sean $\mathrm{WI}^{-}$ LEnTz, We Are Witnessing the Degradation of Democracy, Newsweek, October 25, 2016; IDEm, What We Saw When Trump Took Office: More John C. Calhoun Than Old Hickory, New York Times, January 20, 2017; Idem, No, There is No Precedent, Democracy Journal, no. 46, Fall, 2017; Idem, The Damage Trump Has Done, Rolling Stone, November 30, 2017.

27 Keith E. Whittington - Sean Wilentz, We Are Critics of Nikole Hannab-Jones. Her Tenure Denial is a Travesty, Chronicle of Higher Education, May 24, 2021.

28 Gordon S. Wood, Historian Gordon Wood Responds to the New York Times's Defense of the 1619 Project, World Socialist Web Site, December 24, 2019, at https://www.wsws.org. 


\section{Sean Wilentz}

\section{The 1619 Project and Living in Truth}

\section{Abstract}

The controversy over the New York Times's 1619 Project is the latest in a set of recurring struggles over how American history ought to be taught and understood. The author tells the story of how he came to be involved in the controversy, and how he and a small group of liberal colleagues, objecting to grave factual errors in the project, found themselves increasingly stranded as the debate sharply polarized. Instead of doing their professional duty in keeping the facts straight, the Times editors opted for face-saving evasions, only to see their claims of accuracy and respect for facts collapse. The controversy signals a flattening of historical perspective made worse under the presidency of Donald Trump, promoting cynical, highly ideological claims to the effect that sustaining white supremacy has, since the founding of the U.S., been the nation's core principle and chief mission. Amid the threat to free and honest intellectual discourse which the controversy signifies, American historians must learn the lesson of „living in truth,“ in their historical work as well as in politics.

\section{KEY WORDS:}

1619 Project, New York Times Magazine, Nikole Hannah-Jones, Jake Silverstein, slavery, racism, American Revolution, antislavery, American history, historical studies, Sean Wilentz, Gordon S. Wood, Donald J. Trump, Lerone Bennett Jr., Leslie M. Harris, Alex Lichtenstein, American Historical Review. 